\title{
The Effect of Soy Milk on Mounting Latency, Mounting Frequency, and Reproductive Development in Male Wistar Rats (Rattus Norvegicus)
}

Nurdiana Nurdiana ${ }^{1 *}$ (D), Pradnyawati Chania ${ }^{2}$, Rifzi Nurvitasari ${ }^{2}$, Azmiatun Nisa ${ }^{2}$ (D), Styan Wahyu Diana ${ }^{2}$, Evalina Izzatur Rochmah ${ }^{3}$, Elly Mayangsari ${ }^{1}$, Bambang Rahardjo ${ }^{4}$, Wayan Indrawan ${ }^{4}$, Husnul Khotimah ${ }^{1}$, Karyono Mintaroem ${ }^{5}$ D, Dicky Faizal Irnandi ${ }^{6}$ D

${ }^{1}$ Laboratory of Pharmacology, Faculty of Medicine, Brawijaya University, Malang, Indonesia; ${ }^{2}$ Master Program of Midwifery, Faculty of Medicine, Brawijaya University, Malang, Indonesia; ${ }^{3}$ Bachelor Program of Medicine, Faculty of Medicine, Brawijaya University, Malang, Indonesia; ${ }^{4}$ Departement of Obstetrics and Gynecology, Saiful Anwar General Hospital, Malang, Indonesia; ${ }^{5}$ Laboratory of Anatomical Pathology, Brawijaya University, Malang, Indonesia; ${ }^{6}$ Laboratory of Biochemistry and Biomolecules, Faculty of Medicine, Universitas Brawijaya, Malang, Indonesia

Edited by: Ksenija Bogoeva-Kostovska A B, Indrawan W, Khotimah H, Mintaroem K, Irnandi DF. The Effect of Soy Milk on Mounting Latency, Mounting Frequency, and Reproductive Development in Male Wistar Rats (Rattus Norvegicus). Open Access Maced J Med Sci. 2021 Aug 17; 9(B):670-678 https://doi.org/10.3889/oamjms.2021.641 words: Soy milk, Endocrine-disrupting compounds; Androgen-binding protein: Spermatozoa; Rattus Spermatozoa; Rattus *Correspondence: N. Nurdiana, Laboratory of logy, Faculty of Medicine, Brawijaya University, Jalan Veteran Malang, Kota Malang, Jawa Timur, Indonesia. E-mail: nurdianafarmako.fk@ub.ac.id Received: 08-May-202 Revised: 17-Jun-2021 Copyright: ๑) 2021 Nurdian-Aug-2021 Copyright: ๑ 2021 Nurdiana Nurdiana, dnyawati Chania, Rifzi Nurvitasari, Azmiatun Nisa, Styan Wahyu Diana, Evalina Izzatur Rochmah, Elly Mayangsari, Bambang Rahardjo, Wayan Indrawan, Dicky Faizal Irnand

Funding: This research did not receive any financia Competing Interests: The authors have declared that no competing interests exis Open Access: This is an open-access article distributed under the terms of the Creative Commons Attribution-

\begin{abstract}
AIM: This research aims to examine the effects of soy milk on mounting latency (ML), mounting frequency (MF) estrogen levels, androgen-binding protein (ABP) expression, and spermatogenesis in male rats (Rattus norvegicus).

METHODS: Twenty-four male Wistar rats (R. norvegicus) aged 4 weeks were divided into four groups. Control group (given a normal diet), P1; P2; and P3 (given the normal diet and soy milk powder at doses of 7.1; 14.2; and 21.3 g/ $\mathrm{KgBW} /$ day, respectively) for 6 weeks. Observation of ML and MF was performed at 9 weeks 5 days of age, and rat surgery was performed at 10 weeks of age. Analysis of estrogen hormone levels was conducted by enzyme-linked immunosorbent assay, ABP staining was using immunohistochemistry method, testicular spermatogenesis was observed using histopathological methods, and observation of spermatozoa was performed under the microscope.

RESULTS: The results showed no significant reduction of ML and MF, estrogen levels, and ABP expression ( $p \leq 0.256$ 0.865 ; and 0.959 , respectively) in male rat, but there was a significant decrease in the number, morphology, motility of spermatozoa, and testicular histopathology, ( $\leq \leq 0.000,0.003,0.008$, and 0.000 , respectively).

CONCLUSION: The administration of soy milk in various doses $(7.1 ; 14.2$; and $21.3 \mathrm{~g} / \mathrm{KgBW} /$ day) in male Wistar rats $(R$. norvegicus) had showed significantly difference on histopathological evaluation using Johnson's scoring system, sperm quantity and quality, while on ML and frequency, estrogen levels, and ABP expressions did not show significantly difference between groups. That describe of isoflavone in soy milk can affect several aspects related to male endocrine and reproductive development.
\end{abstract}

\section{Introduction}

Soy milk is a beverage that is easily found in everyday life in Indonesian society. It is often used as a substitute for breast milk and cow milk. Soy milk contains high isoflavones, the bioactive compounds that have biological activity similar to estrogen, and often referred to as phytoestrogens [1]. Phytoestrogens are very similar in chemical structure to mammalian estrogens, estradiol, and are able to bind to alpha and beta estrogen receptors [2], [3], [4]. Apart from having beneficial health effects, the estrogenic properties of phytoestrogens are often being a concern, because they can act as endocrine-disrupting chemicals (EDCs), which have the potential to cause adverse health effects. EDC is natural or synthetic compound that can change hormonal function by various mechanisms. Due to its active compound, soy intake has the potential to cause adverse health effects under certain circumstances, particularly when exposure occurs during developmental time [5].

It was found that soybean extract decreased the levels of follicle stimulating hormone (FSH) and luteinizing hormone $(\mathrm{LH})$ on male Wistar rat pups whose mother was given soy extract during pregnancy and breastfed the cubs until 2 months of age [6]. There was also a decrease in testosterone levels and abnormalities of spermatogenesis. The decrease in testosterone levels also causes a decrease in aromatization of androgens to estrogen; hence, 
isoflavones act as estrogen agonists and bind to ER in the epididymis, prostate, and testicular tissue so as to stimulate estrogen secretion [7].

Androgen is steroid hormone that plays a role in regulating sexual behavior, especially through increased of appropriate stimuli, their effect on synthesis of enzymes, receptors, and/or proteins that affect neurotransmitter function. The androgen receptor (AR) in medial preoptic area (MPOA) contributes to the copulation ability of male rats [8]. Phytoestrogens can inhibit the binding of dihydrotestosterone (DHT) and $A R$ by binding competitively to AR and inhibiting AR-mediated transactivation. The action of androgens on the target tissue results in a masculinizing effect, is partly responsible for continued spermatogenesis in the testes, increases in aggression and sexual behavior. The testosterone produced by the testes is the most active androgen [7]. Testosterone plays a major role in regulating male sexual behavior. The effects of testosterone on sexual behavior are mediated in the brain directly through AR and indirectly (after local aromatization to estradiol) through ER, particularly the estrogen receptor alpha $(E R \alpha)$. The brain areas involved in regulating male sexual behavior, especially in the hypothalamus and preoptic areas, one of which is MPOA, an important integrative core in male sexual behavior [9].

The presence of phytoestrogens which inhibits the production of testosterone may affect the work of androgen and $\mathrm{ABP}$ receptors which have a role in the formation of testosterone and differentiation of sexual cells in males [10]. Phytoestrogens can also affect the bioavailability of sex hormones by binding to or stimulating sex hormone binding globulin (SHBG) synthesis. Some phytoestrogens exert an inhibitory effect on steroidogenic enzymes, for instance, isoflavonoids and lignans inhibit $5 \alpha$-reductase activity, thereby reducing the conversion of testosterone to the active form DHT [11].

The reproductive ability of male animals can be determined by the quality and quantity of semen produced. Good semen quality can be seen from the percentage of normal spermatozoa and their motility. It indicates that the administration of soy isoflavones showed a response to a decrease in the mean number of rat spermatozoa [12], it is suspected that isoflavones are estrogen agonists that can bind to ER and stimulate an estrogen response so that it can interfere with spermatogenesis [3]. The disruption of spermatogenesis and infertility is caused by phytoestrogen compounds in soybean extracts which can downregulate mRNA from FSH receptors, inhibin $\alpha, I N H \beta B, A B P$, and transferrin in Sertoli cells [13].

As the public's consumption of soy milk increases, greater concern and consideration of the properties of soy as EDCs by nutritionists and other health practitioners are needed. The consumption of soy milk by infants and young children is of particular concern because their hormone-sensitive organs, including the brain and reproductive system, are still undergoing sexual differentiation and maturation, thus, their susceptibility to the disruptive endocrine activity of soy phytoestrogens may be very high [5]. Human studies have shown the effects of estrogenic chemicals on the reproductive organs of boys. A collaborative cohort study of approximately 1200 boys from women who were exposed to diethylstilbestrol 2-12 g (5 g average), showed an increased incidence of cryptorchidism, epididymal cysts, and infection of the testicles, especially when exposure occurred before $11^{\text {th }}$ weeks of gestation [14]. The objective of this study is to examine the effects of soy milk on mounting latency $(\mathrm{ML})$, mounting frequency (MF), estrogen levels, ABP expression, sperm quantity, and quality also spermatogenesis in male rats.

\section{Materials and Methods}

\section{Research design}

This study used an experimental method using post-test only control group design, to see the effect of soy milk on sexual behavior, estrogen hormone levels, ABP expression, testicular histopathology, and spermatozoa quality in male Wistar rats (Rattus norvegicus). Four groups were obtained: Control (administered with regular diet), and P1-P3 which received the regular diet and soy milk at 7.1, 14.2, and $21.3 \mathrm{~g} / \mathrm{KgBW} /$ day, respectively, for 6 weeks.

\section{Soy milk}

The soy milk used in this study was localbranded powdered soy milk that often used for cow milk substitute in Indonesia and was obtained at a local market. The isoflavone content of this soy milk is $3.8 \mathrm{mg} / 100 \mathrm{~g}$.

\section{Experimental animals}

The population used was a male Wistar rat $(R$. norvegicus) obtained from the Pharmacology Laboratory of the Faculty of Medicine, Brawijaya University, weight of about $62-70 \mathrm{~g}$, and 4 weeks of age. Each rat was given a sufficient space to avoid discomfort or pain.

\section{Animal husbandry}

Rats were kept and adapted in the laboratory for 7 days at constant room temperature $\left(20-25^{\circ} \mathrm{C}\right)$ with regular light and dark cycles, which were 12-h light cycles and 12-h dark cycles. For the housing of the animals, a plastic box was used, each for four 
rats, covered with wire and given a husk mat which was changed every 3 days to prevent infection. The dietary requirement for adult rats was $45 \mathrm{~g} /$ day/head. The normal diet consists of $67 \%$ Comfeed PAR-S (PT JAPFA COMFEED INDONESIA, Jakarta, Indonesia), $33 \%$ flour, and water, given ad libitum. The experimental protocol has been reviewed and approved by the Ethical Committee of Faculty of Medicine, Brawijaya University.

\section{Animal grouping and soy milk administration}

Twenty-four male rats ( $R$. norvegicus) were divided into four groups. With one group as a control (without treatment) and the other three groups given different doses of soy milk, each sample in the group was six rats. The details of the group division are as follows: Control group (given a normal diet), P1; P2; and P3 (given the normal diet and soy milk powder at doses of $7.1 ; 14.2$; and $21.3 \mathrm{gr} / \mathrm{KgBW} /$ day, respectively) for 6 weeks. The dose of soy milk given was adapted from a study by Nurdiana et al. [15] where soy milk with isoflavone content of $3.53 \mathrm{mg} / 100 \mathrm{~g}$ milk had a spermatogenesis-reducing effect in male rats.

Milk is made by mixing powdered soy milk containing isoflavones with warm water with a maximum volume of 3cc. Soy milk was given orally. Soy milk was started at 4 weeks of age and was given for 6-10 weeks of age. The timing was based on the age of the young rats at weaning ( 4 weeks), and the age of the adult rats when they reached reproductive and sexual maturity (10 weeks) according to Sengupta [16]. The provision of soy milk was conducted by means of a sonde and was given a maximum of 2 times a day (morning and afternoon).

\section{$M L$ and MF test procedure}

$\mathrm{ML}$ is the time it takes for the male to respond to the presence of an estrous female calculated from the time the female is inserted into the cage until the male rat carries out the first mounting attempt by lifting the front of the body over the hindquarter of the female (hindquarter), and grasping the female's pelvis with her forepaws [17]. The MF, calculated by observing the number of times the male mounts it in $20 \mathrm{~min}$ (1200 s).

$\mathrm{ML}$ and MF were conducted $1 \mathrm{~h}$ after giving the last treatment in the dark laboratory room. After being treated, the male rat tested was put in a plexiglass cage measuring $25 \times 25 \times 32 \mathrm{~cm}, 1$ male rat each cage. Ten minutes later, an estrus female rat (1:1) was introduced. Induction of estrus was performed by giving estradiol valerate $2 \mathrm{~m} / 200 \mathrm{~g}$ BW orally $48 \mathrm{~h}$ before observation (estradiol valerate, known as natural estrogen will replace the use of ethinyl estradiol to minimize the risk of thromboembolism) and medroxyprogesterone $0.125 \mathrm{mg} / 20 \mathrm{~g}$ subcutaneous weight $6 \mathrm{~h}$ before observation [18]; determination of the estrous cycle based on observation of the vaginal opening appears open, slightly swollen, wet, and pink and moist in color [19]. The determination of $\mathrm{ML}$ and MF was based on observations of the activity of rats recorded by camera.

\section{(ELISA)}

\section{Enzyme-linked immunosorbent assay}

Analysis of estrogen levels was performed using an ELISA brand BT-Lab E0176Ra. The analytical procedure was performed according to the manufacturer's instructions.

\section{Dissections}

The anesthetic drug used was ketamine at a dose of $0.2 \mathrm{~mL}$. The rats that were already under anesthesia were then placed on the surgical table and fixed, then surgery and organ harvesting were performed. Then, the testis organs are taken and separated with the epididymis and vas deferens.

\section{Tissue preparation}

Testicular tissue is fixed in $10 \%$ neutral buffered formalin for at least $24 \mathrm{~h}$ to prevent autolysis and tissue decomposition. After fixation, the tissue is cut using a scalpel so that it is possible to insert it into the tissue cassette and label it. Then, the tissue is processed into microscopic parts by going through the dehydration, clearing, and embedding stages. Dehydration is done by immersing the tissue in several concentrations of alcohol to remove water and formaldehyde, clearing is done to clean the remaining alcohol. The final step is embedding, which is inserting the tissue into a paraffin block to produce a very thin piece of tissue. The paraffin block was cut using a microtome (4-5 micrometers) to produce a very thin section of tissue, after which it was transferred to a warm water bath [20].

\section{Making histopathological preparations}

The histopathological preparations were made using the paraffin block method. The testicular tissue that has been fused was followed by rinsing using water for at least $1.5 \mathrm{~h}$. The tissue was added with $70 \%$ alcohol for $1 \mathrm{~h}, 80 \%$ alcohol for $1 \mathrm{~h}, 99 \%$ alcohol for $1 \mathrm{~h}$, and absolute alcohol for $2 \times 1 \mathrm{~h}$ then immersed in a mixture of xylol: absolute alcohol $=1: 1$ for $0.5 \mathrm{~h}$, and xylol PA for $2 \times 30 \mathrm{~min}$. The tissue was cut as thin as possible and put in melted paraffin: $x y l e n e=1$ : 1 for $1 \mathrm{~h}$, paraffin $(54-58)$ for $2 \times 1 \mathrm{~h}$. The liquefied parrafin was put into a cubeshaped mold and then placed in the desired position then watered again with sufficient paraffin. The 
chilled paraffin block was removed from the mold. Then, the back of the paraffin block was placed on the microtome with a position indicator that shows the thickness of the cut $(4-5 \mu \mathrm{m})$. The cut results with a microtome in the form of ribbons were then transferred to a warm water bath $\left(45^{\circ} \mathrm{C}\right)$ to stretch the paraffin parts. A preparate or glass object was placed on the underside of the selected tissue and then removed from the warm water bath, after which it was allowed to dry for $24 \mathrm{~h}$, preferably in a thermostatic laboratory oven at $37^{\circ} \mathrm{C}$ [21].

\section{Immunohistochemistry (IHC)}

Testis tissue preparations were given retrieval antigen using citrate buffer, then rinsed using PBS for $3 \times 5 \mathrm{~min}$. After that, the endogenous enzyme blocking used $3 \% \mathrm{H}_{2} \mathrm{O}_{2}$, gave primary antibody (ABP/SHBG polyclonal antibody catalog number BS-2410R) which has been dissolved in PBS $5 \%$ with a ratio of $1: 100$, then incubated in a staining chamber at $4^{\circ} \mathrm{C}$ overnight. PBS was used for washing. Then, testes testis preparates were incubated with biotinylated anti-rabbit immunoglobulin $\mathrm{G}$, diluted in PBS 1:200, containing $1 \%$ bovine serum albumin for $2 \mathrm{~h}$, go on horseradish peroxidase streptavidin (SA-HRP) was applied in e dilution of 1:200 in PBSBSA for $2 \mathrm{~h}$. Immune precipitates were visualized with diaminobenzidine, after staining for $5 \mathrm{~min}$, testis preparates were rinsed in distilled water, applied counterstain with Mayer's hematoxylin and mounted in Entellan [22].

ABP expressions were observed qualitatively. Immunohistochemical stained was observed and photographed using an Olympus BX51 microscope with a magnification of 400 times. Furthermore, observations were made using the image software $\mathrm{J}$. ABP expressions were expressed in the number of Sertoli cells, which were brown in the cytoplasm in ten visual fields.

\section{Histopathological evaluation of testis tissue}

The tissue section was deparaffinized with xylol, rehydrated with water and alcohol, and then stained with the hematoxylin-eosin (HE) method. The slides were examined under a light microscope at $\times 400$ magnification [23]. For histopathological evaluation, four seminiferous tubules in each animal (number of animals in each group $=6$ ) were randomly selected. The Johnson Score classification system was used to assess spermatogenesis quantitatively and is summarized in Table 1. Each tubule was given a score of 1-10 based on the most mature germ cells. The mean score of each animal was analyzed and compared [24].
Table 1: Johnson's scoring system

\begin{tabular}{ll}
\hline Score & Histopathology criteria \\
\hline 10 & $\begin{array}{l}\text { Complete spermatogenesis with many spermatozoa and organized germinal } \\
\text { epithelium }\end{array}$ \\
9 & Many spermatozoa present and disorganized germinal epithelium \\
8 & Few spermatozoa $(<5)$ and a few late $(<5)$ spermatids present \\
7 & Many early spermatids present but no spermatozoa or late spermatids \\
6 & Few early spermatids $(<5)$ present but no spermatozoa or late spermatids \\
5 & Many spermatocytes present but no spermatozoa or spermatids \\
4 & Few spermatocytes $(<5)$ present but no spermatozoa or spermatids \\
3 & Only spermatogonia present \\
2 & Only Sertoli cells present and no germinal epithelium \\
1 & No Sertoli cells and no germinal epithelium present \\
\hline
\end{tabular}

\section{Sperm quantity and quality}

\section{Suspension manufacturing stage}

The left and right epididymal cauda were taken, put in a Petri dish containing $0.9 \% \mathrm{NaCl}$ solution, chopped with a scapula until the liquid was cloudy. The spermatozoa suspension obtained was used for analysis of the number, morphology, and movement of the spermatozoa.

\section{Number of spermatozoa}

The spermatozoa obtained were diluted 10,000 times. Dilution was done by taking $0.1 \mathrm{~mL}$ of spermatozoa suspension and adding $0.9 \mathrm{~mL}$ of $0.9 \%$ $\mathrm{NaCl}$ (dilution 100 times). Then, $0.1 \mathrm{~mL}$ of suspension of spermatozoa was taken and $0.9 \mathrm{~mL}$ of $0.9 \% \mathrm{NaCl}$ was added (dilution 1000 times). After that, $0.1 \mathrm{~mL}$ of spermatozoa suspension was taken and $0.9 \mathrm{~mL}$ of $0.9 \% \mathrm{NaCl}$ was added (dilution 10,000 times) [25]. The spermatozoa concentration was calculated using a hemocytometer. A total of $10 \mu$ of the sample were inserted into the hemocytometer boxes and closed with a cover glass. The hemocytometer was placed under a light microscope with 400 times magnification and the number of spermatozoa is counted in one box $A, B, C$, or D using the formula [26].

Information:

$\mathrm{n}$ : the number of spermatozoa in 4 plane boxes

p: dilution

v: chamber volume count

\section{Spermatozoa motility (movement)}

$10 \mu \mathrm{l}$ of the spermatozoa suspension was dropped on a glass slide then covered with a cover glass, allowed to stabilize for $1 \mathrm{~min}$, then observed using a light microscope with 400 times magnification and then assessed the motility of the spermatozoa. The spermatozoa motility category consists of motility $A$, the movement of the spermatozoa is straight forward and fast (progressive); motility $B$, spermatozoa movement in place (non-progressive); and motility $\mathrm{C}$, the spermatozoa are stationary or immobile. Examined 4-6 fields of view to obtain 100 spermatozoa consecutively, 
then classified so as to yield the percentage of each motility category [27]. Observations were made on spermatozoa with motility category $A$.

\section{Spermatozoa morphology}

Morphological observations used the SafraninCrystal Violet staining method, which was by making a $5 \mu \mathrm{l}$ smear of sperm on a glass object and fixing it using $99 \%$ methanol for 5 min. Evenly with safranin for 5 min then dipped in phosphate buffer $\mathrm{pH} 6.8$ then immediately removed. Then, evenly distributed with $0.25 \mathrm{~g} \%$ crystal violet acetate Ph 2.4 buffer for $5 \mathrm{~min}$. Then, it was rinsed and waited to dry [27]. Morphological observations were conducted under a light microscope with 400 times magnification of 100 spermatozoa; the results were averaged and expressed in percent [28]. Observations were made on spermatozoa with no abnormalities in the head, neck, and tail.

\section{Statistics}

We used SPSS 23 software for windows. Sexual behavior (ML and MF), estrogen levels, ABP expression, and spermatogenesis variable (spermatozoa's number, spermatozoa's number with normal morphology and normal movement, and histopathology testis using Johnson's scoring system) were parametric numbers and presented by mean and standard deviation (SD). We used ANOVA to compare the mean of variables in control group with treated group. If the result showed significantly difference ( $p$ $<0.05)$, continue with post hoc analysis using least significance different.

\section{Results}

Table 2 showed the mean \pm SD also p-value about ML, MF and development reproduction in male Wistar rats after administration soy milk for 6 weeks. There was no statistical differences were found in the ML ( $p \leq 0.987)$ and MF ( $p \leq 0.256)$ of male Wistar rats. The effect of soy milk on estrogen levels is presented in the mean for each treatment group which not significantly different between groups ( $p \leq$ $0.865)$. Soy milk effect on androgen-binding protein (ABP) expressions is presented by calculating the cells mean in each treatment group (Table 2 and Figure 1) which ABP expressions were not significantly difference between groups ( $p \leq 0,959)$. The sperm quantity and quality showed that the number was significantly different in each group ( $p \leq 0.001$ ), the number of spermatozoa with normal morphology was significantly different ( $p \leq 0.003$ ) and showed various spermatozoa morphologies in each treatment group
Table 2: Effect of soy milk on mounting latency, mounting frequency and reproduction development in male Wistar rats (Rattus norvegicus)

\begin{tabular}{|c|c|c|c|}
\hline Variable & Group & Mean \pm SD & p-value \\
\hline \multirow{4}{*}{ Mounting latency } & $\mathrm{K}$ & $72.17 \pm 31.301$ & 0.987 \\
\hline & P1 & $69.83 \pm 42.064$ & \\
\hline & P2 & $64.25 \pm 38.222$ & \\
\hline & P3 & $64.50 \pm 53.898$ & \\
\hline \multirow[t]{4}{*}{ Mounting frequency } & $\mathrm{K}$ & $5.33 \pm 1.751$ & 0.256 \\
\hline & P1 & $4.33 \pm 3.077$ & \\
\hline & P2 & $4.00 \pm 4.099$ & \\
\hline & P3 & $2.00 \pm 1.673$ & \\
\hline \multirow[t]{4}{*}{ Estrogen level } & $\mathrm{K}$ & $34.22 \pm 1.46$ & 0.867 \\
\hline & P1 & $34.58 \pm 0.93$ & \\
\hline & $\mathrm{P} 2$ & $34.42 \pm 0.32$ & \\
\hline & $\mathrm{P} 3$ & $34.67 \pm 0.97$ & \\
\hline \multirow[t]{4}{*}{ Expression of androgen binding protein (abp) } & $\mathrm{K}$ & $56.00 \pm 29.052$ & 0.959 \\
\hline & P1 & $52.67 \pm 9.993$ & \\
\hline & P2 & $50.83 \pm 23.293$ & \\
\hline & P3 & $50.33 \pm 8.847$ & \\
\hline \multirow[t]{4}{*}{ Number of spermatozoa } & $\mathrm{K}$ & $1.31 \pm 0.04$ & 0.000 \\
\hline & P1 & $0.78 \pm 0.06$ & \\
\hline & P2 & $0.20 \pm 0.02$ & \\
\hline & P3 & $0.14 \pm 0.01$ & \\
\hline \multirow[t]{4}{*}{ Number of spermatozoa with normal morphology } & $\mathrm{K}$ & $63.83 \pm 3.920$ & 0.003 \\
\hline & P1 & $58.33 \pm 5.391$ & \\
\hline & P2 & $54.17 \pm 4.535$ & \\
\hline & P3 & $51.67 \pm 6.121$ & \\
\hline \multirow[t]{4}{*}{ Number of spermatozoa with normal movement } & $\mathrm{K}$ & $65.50 \pm 5.541$ & 0.008 \\
\hline & P1 & $57.67 \pm 9.993$ & \\
\hline & $\mathrm{P} 2$ & $54.50 \pm 8.939$ & \\
\hline & $\mathrm{P} 3$ & $47.33 \pm 6.890$ & \\
\hline $\begin{array}{l}\text { Information: Mounting latency (seconds), Mounting frequen } \\
\text { of androgen binding protein (\%), Number of spermatozoa ( } \mathrm{n} \\
\text { morphology }(\%) \text {, Number of spermatozoa with normal move } \\
\text { dose of 7.1. } \mathrm{g} / \mathrm{KgBW} / \mathrm{day}, \mathrm{P} 2=\text { Soy milk dose of } 14.2 \mathrm{~g} / \mathrm{KgB} \\
\text { day. }\end{array}$ & (time & $\begin{array}{l}\text { ogen Levels }(\mathrm{ng} / \mathrm{L}) \text {, } \\
\text { mber of spermatozo } \\
\text { Control group; } \mathrm{P} 1= \\
\text { oy milk dose of } 21.3\end{array}$ & $\begin{array}{l}\text { ression } \\
\text { th normal } \\
\text { / milk }\end{array}$ \\
\hline
\end{tabular}

(Figure 2) also there was significantly differences that were found in the number of spermatozoa with normal movement $(p \leq 0.008)$.

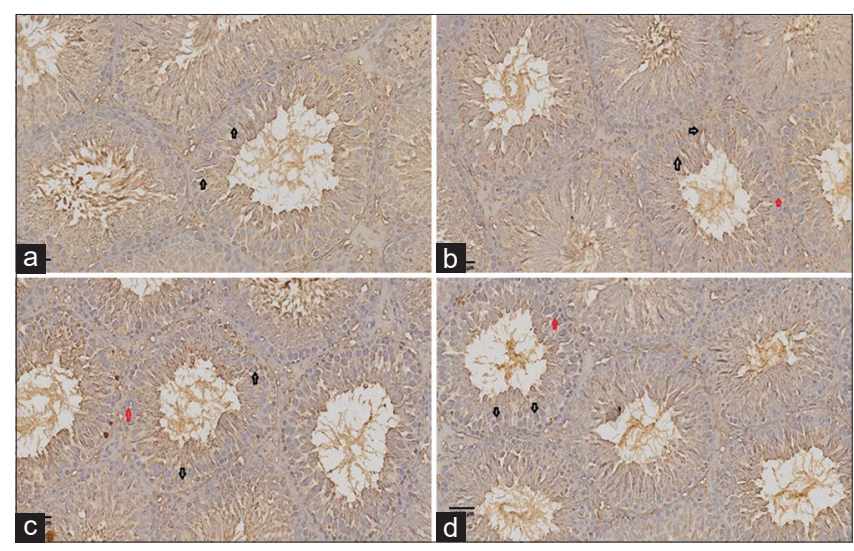

Figure 1: Cross-sectional section photomicrograph of rat testes with immunohistochemical staining. Black arrow showed positive ABP cell staining with brown color and red arrow showed negative $A B P$ cell staining with blue color; (a) control group, (b) treatment Group 1 with soy milk dose $7.1 \mathrm{~g} / \mathrm{KgBW} /$ day, (c) treatment Group 2 with soy milk dose $14.2 \mathrm{~g} / \mathrm{KgBW} /$ day, (d) treatment Group 3 with soy milk $21.3 \mathrm{~g} /$ $\mathrm{KgBW} /$ day (magnification $\times 400$ )

Changes in the histological feature of testicular tissue for each treatment group after being given soy milk are presented in Figure 3.

In control group, it can be observed the most complete cell layer and there are no histopathological changes. The mean Johnson score in this group was 9.75 indicating normal spermatogenesis with many spermatozoa, layers of germinal epithelium arranged in regular thickness, and uniform tubules. In Group 1 treated with soy milk $7.1 \mathrm{mg} / \mathrm{kg}$, the average Johnson score decreased by $5.12 \%$ compared to the control 


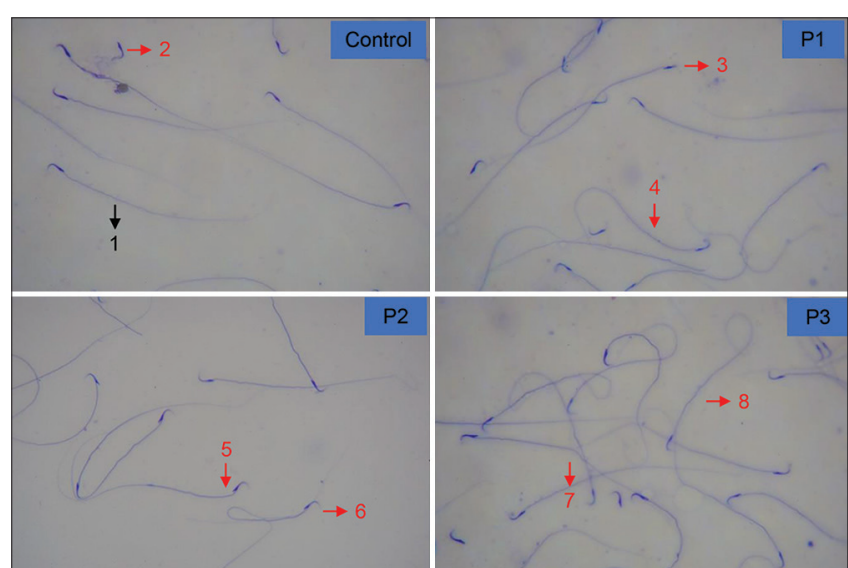

Figure 2: Normal and abnormal morphology of wistar rat sperm with Crystal-Violet staining (magnification of $\times 400$ ). Black arrow: (1) Spermatozoa with normal morphology; Red arrows: Spermatozoa with abnormal morphology include: (2) Spermatozoa without tail; (3) Flattened head; (4) Curved tail; (5) Bent neck; (6) The ends of the tail and head meet; (7) Bent tail; (8) Coiled tail. Control group, P1: treatment with soy milk dose $7.1 \mathrm{~g} / \mathrm{KgBW} /$ day, P2: Treatment with soy milk dose $14.2 \mathrm{~g} / \mathrm{KgBW} /$ day, $P 3$ : treatment with soy milk $21.3 \mathrm{~g} /$ $\mathrm{KgBW} / \mathrm{day}$

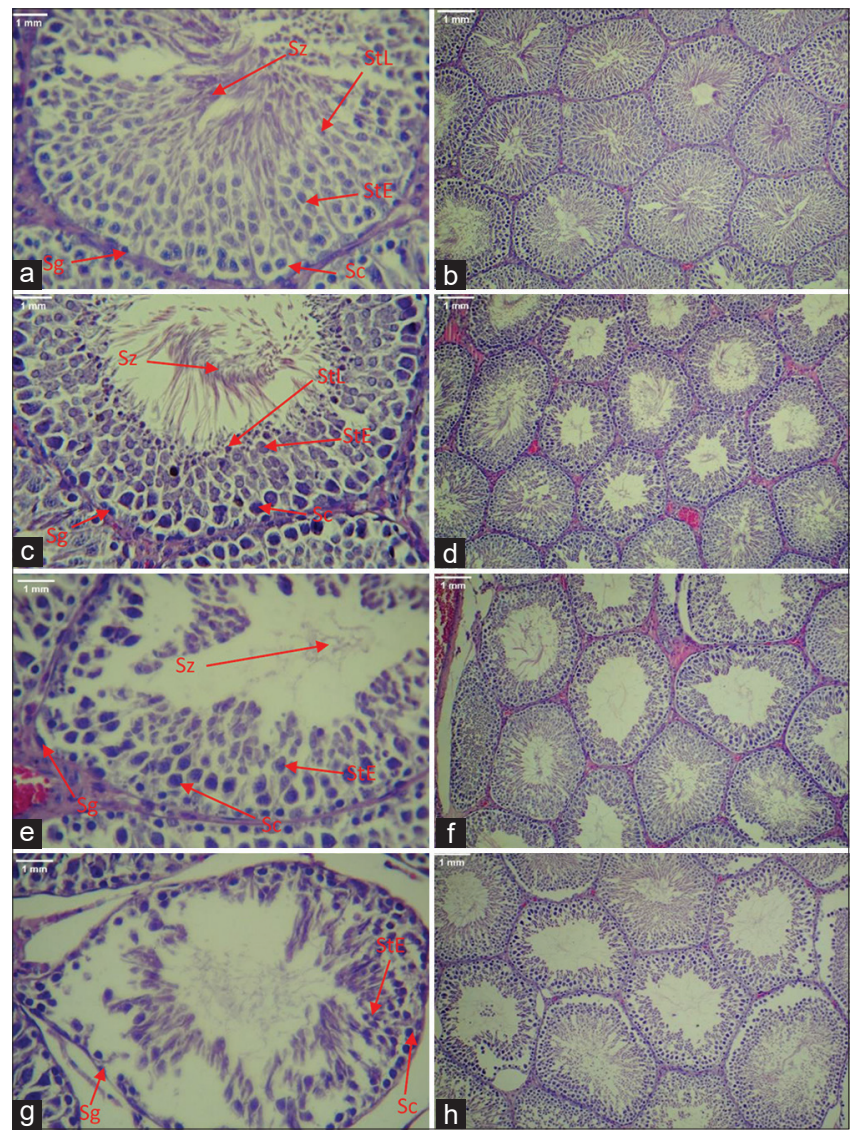

Figure 3: Photomicrograph of cross-sectional section of rat testes with HE staining. (a and b) Control group, (c and d) soy milk treatment group $7.1 \mathrm{~g} / \mathrm{KgBW} /$ day, (e and f) soy milk treatment group $14.2 \mathrm{~g} / \mathrm{KgBW} /$ day, $(\mathrm{g}$ and $\mathrm{h}$ ) treatment group $21.3 \mathrm{~g} / \mathrm{KgBW} /$ day. The testes in the control group and treatment Group 1 indicated normal histology, while the testes in the treatment Group 2 and treatment Group 3 showed mild injuries, including atrophy, reduced germ cell count, and basement membrane damage. (Sg: Spermatogonia, Sc: Spermatosit, StE: Early spermatid, StL: Late spermatid, Sz Spermatozoa) (Magnification $\times 400$ and $\times 100$ ) group ( $p \leq 0.05$ ) but was still categorized as normal spermatogenesis. This group shows a complete germinal epithelial layer but is decreasing in number. In Group 2, treated with soy milk $14.2 \mathrm{mg} / \mathrm{kg}$, the average Johnson score decreased compared to the control group by $14 \%$ and Group 1 ( $p \leq 0.05$ ) by $9.4 \%$. This group showed mild spermatogenetic damage characterized by very few spermatozoa, thinning of the late spermatid layer, slight sloughing of the germ epithelial cells, and irregular arrangement. In Group 3 which was given soy milk $21.3 \mathrm{mg} / \mathrm{kg}$ the average Johnson score decreased significantly compared to the control group by $25.2 \%$, Group 1 by $21.1 \%$, and Group 2 by $13 \%$ ( $p \leq 0.05)$. The features of this group were categorized as mild spermatogenetic damage. They have neither spermatozoa nor late spermatids, worse epithelial disintegration, and damage to the basement membrane. Figure 4 showed that there were changes in the structure and morphology of the seminiferous tubules in the group treated with soy milk.

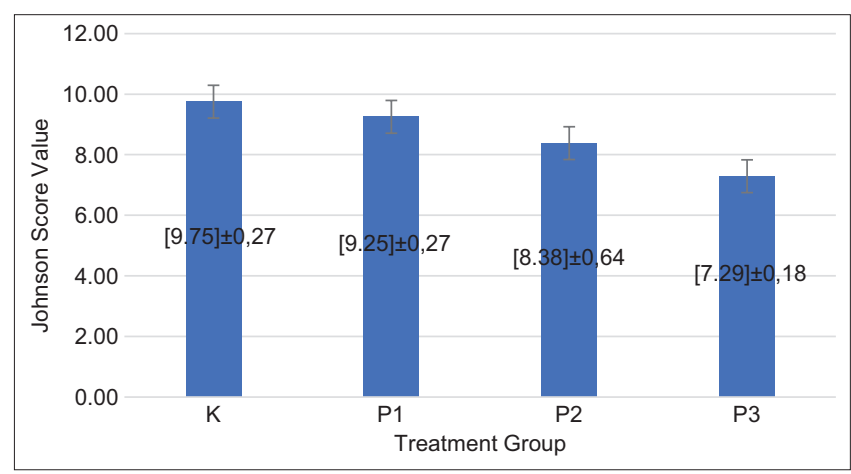

Figure 4: The mean $\pm S D$ histogram of the Johnson score in the four treatment groups; $(K)$ control group, without treatment $(P 1)$ treatment Group 1 given soy milk $7.1 \mathrm{~g} / \mathrm{KgBW} /$ day (P2) treatment Group 1 given soy milk $14.2 \mathrm{~g} / \mathrm{KgBW} /$ day $(P 3)$ treatment Group 1 who were given soy milk $21.3 \mathrm{~g} / \mathrm{KgBW} / \mathrm{day}$

\section{Discussion}

This study was done to identify the effect of soy milk on sexual behavior, estrogen levels, ABP expression, and spermatogenesis in rats ( $R$. norvegicus) if they were given from 4 weeks until 10 weeks age. After the experiment was carried out for 6 weeks, the rats were dissected.

$\mathrm{ML}$ and MF are two of the most important aspects to assess about sexual behavior [29]. With the presence of phytoestrogens as endocrine disruptor that can bind antagonistically to ER [4], [11], and can downregulate AR [8], it should have changed the sexual behavior of male rats, since sexual behavior of male rats was influenced by ER and AR in MPOA [30]. However, hormonal effects elsewhere are required for full activation of behavior [30], and a study in sexual behavior in $\mathrm{ER} \alpha$ knock-out rats showed that $\mathrm{ER} \alpha$ was 
not essential during development for the expression of masculine sexual behavior in male rats [31]. In addition, dopamine can activate sexual behavior through mechanisms acting on ER (other than ER $\alpha$ ) or through pathways that are not dependent on estrogen.

A narrative review by Messina et al. [32] stated that there is essentially no clinical study evidence suggesting that exposure to isoflavones affects circulating estrogen levels in men. The reasons for the lack of change in estrogen concentration are unclear. The rate of aromatization of peripheral androgens is greater in estrone than in estradiol [33]. It may be related to differences in the effects of soy milk consumption.

The histology of testes was stained with IHC. In the present study, ABP expressions were not significantly difference between groups. Yin et al. (2014) studied on Sertoli cells in vitro that were treated isoflavones (daidzein and genistein) show not significantly difference of mRNA ABP in each treatment groups [13]. Isoflavone can act agonist and antagonist, in this study isoflavone as agonist that was showed not significantly difference estrogen levels (Table 2). The result of this study relevant with Fang et al. (2017) study that administration of soy formula milk for babies under 1 year old showed not significantly difference in estradiol, FSH, and SHBG levels between formula milk group [34]. Estrogen, $\mathrm{FSH}$, androgen, prolactin, and insulin have role for regulating ABP expression and secretion that produced by Sertoli cells which functions to bind testosterone and provides an androgenic environment for supporting spermatogenesis and sperm maturation process [35].

Based on Table 2, the administration of soy milk had showed significantly difference on sperm quantity and quality. The results of this study are the same as the results of research conducted by Cederroth et al. [36] in male rats that consume foods that contain lots of phytoestrogens in the long term can interfere with the spermatogenesis process, causing a decrease in the number of spermatozoa.

A decrease in the number of spermatozoa with normal morphology, one of which can be caused by a disturbance in the spermatogenesis process due to the isoflavone content found in soy milk, which is indicated by a decrease in spermatogenesis (Figure 4). In line with research conducted by Nurdiana et al. [15] where soy milk exposure reduced spermatogenesis in male rats, disruption of the spermatogenesis process, especially in the spermiogenesis process [12]. A disrupt the physiological processes of reproductive hormones and spermatogenesis resulting in interferes with the integrity of DNA in spermatozoa. DNA in spermatozoa is very susceptible to environmental changes [37]. Spermatozoa morphology could indicate DNA integrity and quality of spermatozoa [38].

The movement (motility) of spermatozoa is very important because it shows the ability of the spermatozoa to conduct the fertilization process [39]. The energy source of the spermatozoa is ATP and is produced by the mitochondria which are located in the flagella (midpiece) [40], [41]. The decrease in spermatozoa motility is due to the influence of interference in the spermatogenesis process due to isoflavones contained in soybeans [12], [42]. The movement of spermatozoa is also influenced by the morphology of the spermatozoa itself, in which the presence of normal morphology can result in increased motility [43], as well as the results of this study regarding the morphology of spermatozoa (Table 2). The results of this study are also in line with research conducted by Sinaga [12] and Adriani and Nita [39] which stated that giving isoflavones contained in soybeans can reduce the quality and quantity of spermatozoa.

The histological analysis in this study shows that the destructive effect of soy milk as an EDC can be caused by increasing levels of the hormone estrogen resulting in an imbalance in the reproductive hormone system [34] [44]. This estrogenic activity triggers various abnormal molecular events that affect the cellular, tissue, and organ levels [45]. Estrogen exposure can decrease the ability to synthesize testosterone by inhibiting genes involved in steroidogenesis (StAR and cyp17 $\alpha 1$ ) and suppressing $\mathrm{GnRH}$ which regulates the hormones FSH and $\mathrm{LH}$ [46]. There is a disturbance in the spermatogenesis process, a decrease in the number of viable sperm, as well as pathological changes such as atrophy, germ cell degeneration, and fibrosis. Hormonal imbalance and damage to the testes after giving soy milk are multifactorials that cause delayed maturation of spermatogonia to reach the next level of cell development, becoming spermatocytes, spermatids, and spermatozoa [47].

Histopathological evaluation using the Johnson score can be a useful tool to measure the endocrinedisrupting effect and predict reproductive ability [48]. Soy milk interferes with the spermatogenesis process in a dose-dependent manner. The highest dose increases resulted in worse testicular tissue damage so that the Johnson score decreased significantly. Meanwhile, the group treated with the lowest dose had the least testicular tissue damage.

\section{Conclusion}

The administration of soy milk in various doses (7.1 g/KgBW/day, $14.2 \mathrm{~g} / \mathrm{KgBW} /$ day, and $21.3 \mathrm{~g} / \mathrm{KgBW} /$ day) in male Wistar rats ( $R$. norvegicus) had showed significantly difference on histopathological evaluation using Johnson's scoring system, sperm quantity and quality, while on sexual behavior ( $\mathrm{ML}$ and frequency) estrogen levels and ABP expressions did not show significantly difference between groups. That describe of isoflavone in soy milk can affect several aspects related to male reproductive development. The possible toxicity effects need further research. 


\section{Ethical approval}

The research was given ethical approval from ethical committee of medical faculty Brawijaya University, Malang.

\section{Author's Contributions}

Nurdiana: Conceptualization, investigation, project administration, writing-reviewed and editing; final approval published version. Made Pradnyawati Chania; Rifzi Devi Nurvitasari; Azmiatun Nisa; Styan Wahyu Diana; Evalina Izzatur Rochmah: Data curation, investigation, methodology, formal analysis, editing, writing-original draft preparation, final approval published version. Bambang Raharjo; I Wayan Agung Indrawan; Husnul Khotimah: Interpretation of data, methodology, writing-original draft preparation, final approved publish version. Karyono Mintareom: Interpretation of IHC result, writing-original draft preparation, final approved publish version. Dicky Faizal Irnandi: Interpretation of sperm quality and quantity method, ML and frequency, final approved publish version.

\section{Acknowledgment}

The authors are very grateful to the assistants of the Pharmacology Laboratory, the Laboratory of Biochemistry and Molecular Biology and the Laboratory of Anatomical Pathology, Faculty of Medicine, Brawijaya University, Malang, East Java, Indonesia.

\section{References}

1. Yulifianti R, Muzaiyanah S, Utomo JS. Soybean as an ingredient in isoflavone-rich foods. Bul Palawija. 2018;16(2):84.https://doi. org/10.21082/bulpa.v16n2.2018.p84-93

2. Rietjens IM, Sotoca AM, Vervoort J, Louisse J. Mechanisms underlying the dualistic mode of action of major soy isoflavones in relation to cell proliferation and cancer risks. Mol Nutr Food Res. 2013;57(1):100-13. https://doi.org/10.1002/mnfr.201200439 PMid:23175102

3. Paterni I, Granchi C, Katzenellenbogen JA, Minutolo F. Estrogen receptors alpha $(E R \alpha)$ and beta $(E R \beta)$ : Subtype-selective ligands and clinical potential. Steroids. 2014;90:13-29. https:// doi.org/10.1016/j.steroids.2014.06.012

PMid:24971815

4. Zin SR, Omar SZ, Ali Khan NL, Musameh NI, Das S, Kassim NM. Effects of the phytoestrogen genistein on the development of the reproductive system of Sprague Dawley rats. Clinics (Sao Paulo). 2013;68(2):253-62. https://doi.org/10.6061/ clinics/2013(02)oa21

\section{PMid:23525324}

5. Patisaul HB. Endocrine disruption by dietary phyto-oestrogens: Impact on dimorphic sexual systems and behaviours. Proc Nutr Soc. 2016;76(2):130-44. https://doi.org/10.1017/ s0029665116000677

PMid:27389644

6. Nurdiana N, Mayangsari E, Lestari B, Setiawan B. Hormonal changes and spermatogenesis of male rat puppies born by mothers consuming soybean extract. Asian Pac J Reprod. 2016;5(6):506-9. https://doi.org/10.1016/j.apjr.2016.10.009

7. Kumar A, Sharma M. Basics of human andrology. In: Basics of Human Andrology. Berlin: Springer; 2017.

8. Wu D, Gore AC. Changes in androgen receptor, estrogen receptor alpha, and sexual behavior with aging and testosterone in male rats. Horm Behav. 2010;58(2):306-16. https://doi. org/10.1016/j.yhbeh.2010.03.001

PMid:20223236

9. Swaney WT, Dubose BN, Curley JP, Champagne FA. Sexual experience affects reproductive behavior and preoptic androgen receptors in male mice. Horm Behav. 2012;61(4):472-8. https:// doi.org/10.1016/j.yhbeh.2012.01.001

PMid:22266118

10. Ma Y, Yang HZ, Xu LM, Huang YR, Dai HL, Kang XN Testosterone regulates the autophagic clearance of androgen binding protein in rat Sertoli cells. Sci Rep. 2015;5:8894. https:// doi.org/10.1038/srep08894

PMid:25745956

11. Retana-Márquez $S$, Hernández $\mathrm{H}$, Flores JA, Muñoz-Gutiérrez $M$, Duarte G, Vielma J, et al. Effects of phytoestrogens on mammalian reproductive physiology. Trop Subtrop Agroecosyst. 2012;15 Suppl 1:S129-45.

12. Sinaga ES. The effect of soy isoflavones on the speed and morphology of spermatozoa in male white rats (Rattus norvegicus). J Imelda Midwifery Sci. 2016;2(2):73-85. https:// doi.org/10.22435/mpk.v24i3.3646.123-128

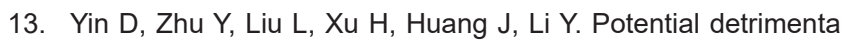
effect of soy isoflavones on testis sertoli cells. Zhong Nan Da Xue Xue Bao Yi Xue Ban. 2014;39(6):598-604.

PMid:25011964

14. Palmer JR, Herbst AL, Noller KL, Boggs DA, Troisi R, TitusErnstoff $\mathrm{L}$, et al. Urogenital abnormalities in men exposed to diethylstilbestrol in utero: A cohort study. Environ Health. 2009;8(1):37. https://doi.org/10.1186/1476-069x-8-37 PMid: 19689815

15. Nurdiana N, Sarwono I, Setyohadi R, Harsono S, Budiutomo P, Adiguna $\mathrm{F}$, et al. Effect of soybean milk for 12 weeks in six-weeksold male rats' testis, prostate, epididymis, seminal vesicles and testosterone. Chine J Pharmacol Toxicol. 2015;29(1):83-7.

16. Sengupta $P$. The laboratory rat: Relating its age with human's Int J Prev Med. 2013;4(6):624-30.

PMid:23930179

17. Yakubu MT, Akanji MA. Effect of aqueous extract of massularia acuminata stem on sexual behaviour of male wistar rats. Evid Based Complement Alternat Med. 2011;2011:738103. https:// doi.org/10.1155/2011/738103 PMid:21253466

18. Ahrendt $\mathrm{HJ}$, Adolf $\mathrm{D}$, Buhling $\mathrm{KJ}$. Advantages and challenges of oestrogen-free hormonal contraception. Curr Med Res Opin. 2010;26(8):1947-55. https://doi.org/10.1185/03007995.2010.49 3088

PMid:20569066

19. Ajayi AF. Staging of the estrous cycle and induction of estrus in experimental rodents: An update. Fertil Res Pract. 2020;6:5. https://doi.org/10.1186/s40738-020-00074-3 


\section{PMid:32190339}

20. Llewellyn BD. How to Prepare Histology Slides; 2013. Available from: http://www.ivy-rose.co.uk/humanbody/histology/how-toprepare-histology-slides.php. [Last accessed on 2020 Dec 20].

21. Slaoui M, Fiette L. Histopathology procedures: From tissue sampling to histopathological evaluation. Methods Mol Biol. 2011;691:69-82. https://doi.org/10.1007/978-1-60761-849-2_4 PMid:20972747

22. HerbertZ, Weigel S, Sendemir E, MarshallA, Caldwell JD, Petrusz $\mathrm{P}$, et al. Androgen-binding protein is co-expressed with oxytocin in the male reproductive tract. Anat Histol Embryol. 2005;34(5):28693. https://doi.org/10.1111/j.1439-0264.2005.00605.x PMid:16159369

23. Sahu C, Dwivedi DK, Jena GB. Zinc and selenium combination treatment protected diabetes-induced testicular and epididymal damage in rat. Hum Exp Toxicol. 2020;39(9):1235-56. https:// doi.org/10.1177/0960327120914963

PMid:32233808

24. Mushtaq $\mathrm{H}$, Alam S, Khan MA. Histopathological patterns of testicular biopsies in male infertility. J Islam Med Dent Coll. 2013;4(2):81-6.

25. Laili N, Hidayati D, Tita D. The effect of cepoka eggplant fruit infusion against white male rats spermatozoa concentration. J Kesehatan Bakti Tunas Husada. 2014;12(1):202-13. https://doi. org/10.36465/jkbth.v12i1.80.

26. Fatmawati D, Isradji I, Yusuf I, Suparmi S. Spermatozoa quality of male Balb/C mice after administration of kepel fruit extract (Stelechocarpus burahol). Maj Kedokt Bandung. 2016;48(3):155-9. https://doi.org/10.15395/mkb.v48n3.845

27. Rompis SA, Tendean LE, Rumbajan JM. Effect of overweight on sperm quality of wistar rats (Rattus norvegicus). J E Biomed. 2018;6(1):39-44. https://doi.org/10.35790/ebm.6.1.2018.18769

28. Malini DM. Effect of ethanol extract and spinasterol of senggugu (Clerodendron serratum L.) leaves on sperm quality of mice (Mus musculus L.). Indonesia J Appl Sci. 2013;3(3):49-54. https://doi.org/10.24198/ijas.v3i3.15042

29. Winarni D. Effects of Javanese and Korean ginseng roo extract on male mice libido in low testosterone precondition. Berk Biol Res. 2007;12(2):153-9. https://doi.org/10.23869/ bphjbr.12.2.20079.

30. Hull EM, Dominguez JM. Sexual behavior in male rodents. Horm Behav. 2007;52(1):45-55.

\section{PMid:17499249}

31. Wersinger SR, Rissman EF. Dopamine activates masculine sexual behavior independent of the estrogen receptor alpha. J Neurosci. 2000;20(11):4248-54. https://doi.org/10.1523/ jneurosci.20-11-04248.2000

PMid:10818161

32. Messina M. Soybean isoflavone exposure does not have feminizing effects on men: A critical examination of the clinical evidence. Fertil Steril. 2010;93(7):2095-104. https://doi. org/10.1016/j.fertnstert.2010.03.002

\section{PMid:20378106}

33. Macdonald PC, Madden JD, Brenner PF, Wilson JD, Siiteri PK Origin of estrogen in normal men and in women with testicular feminization. J Clin Endocrinol Metab. 1979;49(6):905-16. https://doi.org/10.1210/jcem-49-6-905

PMid:511978

34. Fang X, Wang L, Wu C, Shi H, Zhou Z, Montgomery S, et al. Sex hormones, gonadotropins, and sex hormone-binding globulin in infants fed breast milk, cow milk formula, or soy formula. Sci Rep. 2017;7(1):4332. https://doi.org/10.1038/ s41598-017-04610-y

PMid:28659579

35. Munell F, Suárez-Quian CA, Selva DM, Tirado OM, Reventós J. Androgen-binding protein and reproduction: Where do we stand? J Androl. 2002;23(5):598-609.

PMid:12185088

36. Cederroth CR, Zimmermann C, Beny JL, Schaad O, Combepine C, Descombes $\mathrm{P}$, et al. Potential detrimental effects of a phytoestrogen-rich diet on male fertility in mice. Mol Cell Endocrinol. 2010;321(2):152-60. https://doi.org/10.1016/j. mce.2010.02.011

PMid:20171261

37. Irnandi DF, Hinting A, Yudiwati R. DNA fragmentation of sperm in automobile painters. Toxicol Ind Health. 2021;37(4):182-8. https://doi.org/10.1177/0748233721989892 PMid:33594946

38. Agarwal A, Mulgund A, Hamada A, Chyatte MR. A unique view on male infertility around the globe. Reprod Biol Endocrinol 2015;13(1):37. https://doi.org/10.1186/s12958-015-0032-1 PMid:25928197

39. Adriani A, Nita S. Effect of soybean extract (Glycine max) on the quantity and quality of spermatozoa of male white rats (Rattus norvegicus) sprague dawley strain. J Kedokt Yars.2015;23(1):1227. https://doi.org/10.22435/mpk.v24i3.3646.123-128.

40. Luthfi MJ, Noor MM. Sperm Quality Analysis of Experimenta Rats (Quantity, Motility, and Morphology). Surakarta: UNS Press; 2015. p. 59.

41. Agustinus RI, Pramesti MP. Male Reproductive Biology. Surabaya: Airlangga University Press; 2018. p. 1-135. Available from: http://www.library1.nida.ac.th/termpaper6/sd/2554/19755. pdf. [Last accessed on 13 Jan 2021].

42. Kim SH, Park MJ. Effects of phytoestrogen on sexua development. Korean J Pediatr. 2012;55(8):265-71. PMid:22977438

43. Gundogan M, Yeni D, Avdatek F, Fidan AF. Influence of sperm concentration on the motility, morphology, membrane and DNA integrity along with oxidative stress parameters of ram sperm during liquid storage. Anim Reprod Sci. 2010;122(3-4):200-7. https://doi.org/10.1016/j.anireprosci.2010.08.012

PMid:20828947

44. Wang R, Ma X, Liu T, Li Y, Song L, Tjong SC, et al. Degradation aspects of endocrine disrupting chemicals: A review on photocatalytic processes and photocatalysts. Appl Catal A Gen. 2020;597:117547. https://doi.org/10.1016/j.apcata.2020.117547

45. van der Ven LT, Wester PW, Vos JG. Histopathology as a tool for the evaluation of endocrine disruption in zebrafish (Danio rerio). Environ Toxicol Chem. 2003;22(4):908-13. https://doi. org/10.1002/etc.5620220431 PMid:12685728

46. Scholz S, Mayer I. Molecular biomarkers of endocrine disruption in small model fish. Mol Cell Endocrinol. 2008;293(1-2):57-70. PMid:18619515

47. Hassanzadeh N. Histopathological evaluation of the Zebrafish (Danio rerio) testis following exposure to methyl paraben. Int $J$ Aquat Biol. 2017;5(2):71-8.

48. Aydin S, Billur D, Kizil S, Ozkavukcu S, Celikkan FT, Aydos K, et al. Evaluation of blood-testis barrier integrity in terms of adhesion molecules in nonobstructive azoospermia. Andrologia. 2020;52(7):e13636. https://doi.org/10.1111/and.13636 PMid:32453883 